\title{
PERBEDAAN KREDIT BERMASALAH DAN KELANCARAN KAS BERDASARKAN KEPEMILIKAN BANK PERKREDITAN RAKYAT
}

\author{
I NYOMAN NUGRAHA ARDANA PUTRA \\ Fakultas Ekonomi dan Bisnis Universitas Mataram \\ nyoman.nugraha@unram.ac.id \\ BUDI SANTOSO \\ Fakultas Ekonomi dan Bisnis Universitas Mataram \\ hebato@yahoo.com \\ LALU HAMDANI HUSNAN \\ Fakultas Ekonomi dan Bisnis Universitas Mataram \\ Ihkdeby1211@gmail.com
}

\section{Article History:}

Received: 12 Maret 2020

Revised: 16 April 2021

Accepted: 16 April 2021

\begin{abstract}
Abstrak: Tujuan penelitian ini adalah Untuk menganalisis perbedaan BPR Berbadan Usaha PT dengan BPR berbadan Usaha PD ditinjau dari tingkat kredit bermasalah dan tingkat kelancaran kas perusahaan. Penelitian ini merupakan penelitian kuantitatif dengan jenis penelitian komparatif yang membandingkan antara Bank Perkreditan Rakyat (BPR) kepemilikan manajerial dengan BPR kepemilikan pemerintah atau perusahaan daerah yang ada di Nusa Tenggara Barat. Lokasi penelitian pada Bank Perkreditan Rakyat yang ada di Provinsi Nusa Tenggara Barat (NTB) yang tahun 2019 mengalami risiko kredit dan risiko likuiditas yang tinggi. Peningkatan risiko tersebut terjadi menarik utuk dinalisis perbedaan kinerja BPR milik swasta dengan milik pemerintah. Alat analisis yang digunakan adalah uji t (uji beda) independen. Hasil menunjukan bahwa ada perbedaan BPR Perusahaan Daerah dengan BPR Perseroan Terbatas ditinjau dari kelancaran kas sedangkan ditinjau dari kredit bermasalah tidak ada perbedaan diantara kedua bentuk badan usaha tersebut. Implikasi penelitian merekomendasikan mempertahankan keadaan yang sudah ada karena kedua jenis kepemilikan menunjukan performa yang kurang lebih sama
\end{abstract}

Kata Kunci: Kredit Bermasalah, Kelancaran Kas, Kepemilikan Daerah, Perseroan Terbatas

\section{PENDAHULUAN}

Tahun 2009 di Nusa Tenggara Barat telah terjadi proses merger terhadap 46 BPR yang tergolong dalam BPR Lumbung Kredit Pedesaan 
(BPR-LKP) sebagai bentuk Badan Usaha Milik Daerah (BUMD). Tujuan Penggabungan BPR-LKP ini adalah untuk meningkatkan efektivitas, efisiensi dan pengawasan sesuai dengan teori keagenan (Putra, 2013). Tingkat pengawasan pada BPR-LKP yang menggunakan proksi non performing loan (NPL), ternyata pasca dilakukannya merger justru kredit bermasalah yang dihadapi BPR-LKP jauh semakin semakin besar. Dandapani et al. (2017) menegaskan hal tersebut terjadi karena likuiditas dan modal bank yang merger lebih kecil. NPL merupakan sumber masalah dalam BPR karena menurunnya pendapatan dan sekaligus menyebabkan penurunan nilai kas dalam hal ini likuiditasnya.

Ada berita menarik yaitu bahwa Delapan PD. BPR NTB yang tersebar di kabupaten/kota dalam kondisi "sakit". Hal tersebut timbul karena kredit macet atau Non Performing Loan (NPL) berada di atas 5 persen(Suara NTB, 2019), Kenaikan kredit bermasalah pada BPR di NTB tersebut menyebabkan menurunnya jumlah pendapatan yang diperoleh perusahaan. Bahkan menurut Ghosh (2017) NPL menyebabkan penurunan GDP. Turunnya pendapatan BPR tentu saja berdampak pada jumlah kas yang dimilikinya, dan tentu saja semakin terjadi penurunan. Penurunan efisiensi perusahaan akibat kredit macet tersebut menjadi suatu hal yang menarik untuk dikaji karena dalam BPR di NTB sebagian bentuk kepemilikannyanya manajerial dan sebagian lagi kepemilikan oleh pemerintah daerah.

Perbedaan bentuk kepemilikan tersebut memang bertendensi untuk menyebabkan perbedaan performa, seperti penelitian Rashid (2015) dan Du (2013) menunjukkan bahwa kepemilikan manajerial akan meningkatkan efisiensi perusahaan.. Namun menurut Thepot (2015), hal tersesebut bisa terjadi bila pemilik bersifat opportunist (mengejar keuntungan pribadi yang bersifat jangka pendek). Penelitian terdahulu juga ada perbedaan hasil, yaitu penelitian Rubin (2007) menunjukkan bahwa bank dengan kepemilikan institusional memiliki hubungan yang lebih kuat terhadap likuiditas jika dibandingkan dengan bank dengan kepemilikan orang dalam. Namun penelitian Chalermchatvichien et al. (2011) yang mengindikasikan semakin tinggi konsentrasi kepemilikan orang dalam, maka akan meningkatkan likuiditas suatu bank. Sharat \& Pham (2015) menyatakan pola peminjaman dana bank kepemilikan swasta (perseroan) sangat bergantung dari pertumbuhan tabungan dan keterbatasan atau rendahnya likuiditas bank, sedangkan kepemilikan pemerintah bergantung pada penambahan modal pemerintah.

Fenomena yang lagi banyak dibicarakan saat ini terkait dengan akan dilakukannya merger untuk kedua kalinya pada BPR kepemilikan pemerintah daerah (BUMD). Pemerintah Provinsi Nusa Tenggara Barat menargetkan penggabungan BPR NTB mulai 2018 (Lombok Post, 2018). Sebenarnya bukan hanya penggabungan itu hal utamanya, akan tetapi terkait dengan perubahan bentuk badan usaha atau struktur kepemilikan 
dari bentuk Perusahaan Daerah (PD) menjadi Perseroan Terbatas (PT). Upaya swastanisasi atau privatisasi yang akan dilakukan oleh BPR kepemilikan pemerintah daerah ini terkait dengan pengelolaannya menjadi lebih profesional. Penelitian ini memperjelas perbedaan pengelolaan BPR kepemikan pemerintah atau Perusahan Daerah (PD) dibandingkan BPR milik swasta atau yang berbentuk Perseroan Terbatas ditinjau dari NPL dan CR. Hal yang menarik menurut Tan \& Anchor (2017) bahwa bank pemerintah bertendesi memiliki risiko likuiditas dan risiko kredit lebih tinggi. Melalui riset ini diharapkan dapat mengetahui kelebihan dan kekurangan kinerja perusahaan yang berbentuk PD dibandingkan dengan berbentuk PT, serta dapat memberi rekomendasi kepada pemerintah.

\section{TINJAUAN LITERATUR}

Agency theory yang disampaikan Jensen \& Meckling (1976), yang menyatakan bahwa kepemilikan manajerial memilliki tendensi untuk mereduksi biaya keagenan dan selain itu melalui teori keagenan meningkatkan kinerja (nilai) perusahaan (Putra,2012). Salah satu untuk cara untuk menekan adanya biaya keagenan adalah kepemilikan manajerial. Pengukuran kepemilikan manajerial pada Bank Perkreditan Rakyat (BPR) digunakan kepemilikan oleh top management (kepemilikan oleh manajemen puncak). Tentunya dalam penelitian ini menguji bahwa kepemilikan manajerial pada BPR memang terjadi reduksi biaya keagenan atau justru sebaliknya bahwa justru pada kepemilikan manajerial terjadi biaya keagenan.

Sabrina dan Muharam (2015) melakukan riset terkait dengan perbedaan risiko kredit, risiko likuiditas dan profitabilitas bank berdasarkan kepemilikan yang berbeda yaitu kepemilikan pemerintah dan kepemilikan oleh orang asing terhadap kinerja profitabilitas. Indikator yang dipergunakan dalam penelitian ini adalah Liquid Asset to TotalAsset (LATA) untuk mengukur risiko likuiditas, Non Performing Loan (NPL) dalam mengukur risiko kredit dan proxy Return On Asset (ROA) dipergunakan dalam mengukur kemampuan profitabilitas perusahaan. Sampel yang diamati adalah bank yang berasal dari populasi seleuruh bank komersial yang melaporkan laporan keuangan selama periode akuntansi 2007 sampai dengan 2011. Terdapat 51 bank yang menjadi pengamatan dengan menggunakan purposive sampling. Hasil penelitian menunjukan bahwa bank kepemilikan asing dan bank kepemilkan pemerintah sama-sama berpengaruh positif terhadap profitabilitas, namun demikian besarnya pengaruh bank kepemilikan asing terhadap profitabilitas lebih besar daripada pengaruh bank kepemilikan pemerintah.

Penelitian Sukendri (2021) melihat perbedaan Likuiditas dan Permodalan Bank Milik Pemerintah sebelum dan pada masa pandemi Covid-19 ditinjau dari likuiditas dan permodalan. Pendekatan yang digunakan dalam penelitian ini adalah penelitian kuantitatif komparatif. 
Ada empat bank milik pemerintah atau Badan Usaha Milik Negara (BUMN) yang diamati yaituBank Rakyat Indonesia (BRI), Bank Mandiri, Bank Negara Indonesia (BNI), Bank Tabungan Negara (BTN). Sebelum dianalisis dilakukan Hasil penelitian menjelaskan bahwa terjadi perbedaan sebelum dan pada masa terjadinya pandemi ditinjau dari segi likuiditas perbankan, dan dilihat dari segi kecukupan modal bank BUMN.

Penelitian Putri dan Damayanti (2013) menguji perbedaan tingkat kesehatan antara bank besar dan bank kecil yang terdaftar di Bursa Efek Indonesia tahun 2011 dan 2012. Penilaian terhadap tingkat kesehatan bank merupakan penilaian terhadap faktor-faktor RGEC yakni profil risiko (risk profile), tata kelola perusahaan yang baik (good corporate governance), rentabilitas (earnings), dan permodalan (capita). Bank yang menjadi sampel sebanyak 17 bank dari populasi 32 bank dengan metode purposive sampling. Berdasarkan hasil pengujian dan pembahasan yang telah diuraikan, maka dapat disimpulkan bahwa pertama, secara parsial terdapat dua faktor dari empat faktor penilaian tingkat kesehatan bank yang tidak signifikan yaitu factor rentabilitas dan permodalan. Penyebabnya adalah rasio ROA dan CAR yang dimiliki bank besar maupun bank kecil sudah memadai dari standar yang ditetapkan BI. Hal tersebut menunjukkan baik bank besar maupun bank kecil memiliki kemampuan menghasilkan laba yang baik dan memiliki kualitas dan kecukupan permodalan yang memadai. Sedangkan dua faktor yang secara statistic menunjukkan adanya signifikansi antara bank besar dan bank kecil yaitu factor profil risiko dan GCG. Penyebab adanya signifikansi untuk faktor profil risiko yaitu bank besar memiliki peringkat profil risiko yang lebih rendah daripada bank kecil. Sedangkan untuk faktor GCG penyebab adanya signifikansi adalah bank kecil memiliki peringkat GCG yang lebih tinggi daripada bank besar. Kedua, penilaian kesehatan bank ditinjau dari faktor RGEC menunjukkan bahwa tidak terdapat perbedaan tingkat kesehatan antara bank besar dan bank kecil. Hal tersebut disebabkan karena hampir setengah dari populasi bank yang terdaftar di BEI pada tahun 2011 hingga 2012 tidak masuk dalam sampel, terbatasnya proksi yang digunakan dan adanya regulasi baru menyebabkan faktor-faktor RGEC belum terstandarisasi secara utuh sehingga menimbulkan penilaian yang subjektif.

Penelitian Anjani dan Pakpahan (2020) bertujuan untuk mendeskripsikan perbedaan pada kinerja keuangan Bank Pemerintah dan Bank Swasta Nasional selama tahun 2014 sampai dengan 2019. Beberapa bank yang menjadi pengamatan adalah bank umum yang tergabung dalam Bank Umum Kelompok Usaha 4 (BUKU 4), yaitu; BRI, BNI, Bank Mandiri, BCA, Bank CIMB Niaga, dan Bank Pan Indonesia. Rasio keuangan yang akan diukur dalam penelitian ini adalah rasio permodalan (CAR), profitabilitas (ROA), kualitas aktiva produktif (NPL), likuiditas (LDR), dan efisiensi (BOPO). Metode penelitian yang digunakan adalah dengan 
membandingkan rata-rata atau mean kedua sampel menggunakan uji Independent Samples T-Test. Hasil dari penelitian ini menunjukkan bahwa bila diukur dari rasio-rasio CAR, NPL, dan LDR, ternyata tidak terdapat perbedaan kinerja keuangan antara bank pemerintah dan bank swasta nasional. Namun jika dilihat dari rasio ROA dan BOPO, menujukkan hasil bahwa terdapat perbedaan kinerja keuangan antara bank pemerintah dan bank swasta nasional.

\section{METODE}

Penelitian ini adalah penelitian komparatif yang membandingkan 29 BPR di Nusa Tenggara Barat (NTB). Jadi ada 21 BPR yang memiliki kepemilikan manajerial yang biasanya berbentuk badan usaha Perseroan Terbatas dan sisanya 8 BPR bentuk badan usahanya Perusahaan Daerah atau kepemilikannya oleh pemerintah daerah. Metode analisis data yang digunakan dalam penelitian ini yaitu dengan analisis uji beda dengan t-test 2 sample independent Analisis perbandingan biasanya digunakan untuk rata-rata diantara atau lebih kelompok sampel data. Asumsi mendasar dalam analisis perbandingan ini adalah bahwa variabel data yang akan dibandingkan harus mengikuti fungsi distribusi normal. Artinya sebelum masuk kedalam uji t, maka diawali dengan melakukan uji normalitas yang biasanya menggunakan uji kolmogorov-smirnov (Ghozali;2005), menggunakan ketentuan sebagai berikut:

- Jika nilai signifikansi > 0,05 maka data berdistribusi normal.

- Jka nilai signifikansi $\leq 0,05$ maka data tidak berdistribusi normal.

Dalam uji perbandingan ini digunakan analisis independent-sample $t$ test. Uji ini membandingkan rata-rata dari dua kelompok sampel data yang independen. Maksudnya diantara kedua hal yang diperbandingkan adalah masing-masing merupakan objek yang berbeda satu sama lainnya. Penggunaan uji independent t-tes ini karena rata-rata yang dibandingkan hanya terdiri dual hal saja, ketika lebih dari 2 maka dianjurkan menggunakan analisis of varians (anova). Uji beda independent t-test ini dilihat dari berbagai hal yaitu

1. Kredit Bermasalah yang menggunakan proxy NPL

2. Kelancaran Kas atau Likuiditas yang menggunakan proxy CR

Hipotesis statistik yang digunakan untuk menguji perbedaan diantara BPR kecil dengan BPR menengah adalah

$\mathrm{H}_{0}$ : Tidak ada perbedaan antara BPR Perseroan (PT) dengan BPR Perusahaan Daerah (PD) baik ditinjau dari Kredit Bermasalah maupun Kelancaran Kas.

$\mathrm{H}_{\mathrm{a}}$ : Ada perbedaan antara BPR Perseroan (PT) dengan BPR Perusahaan Daerah (PD) baik ditinjau dari Kredit Bermasalah maupun Kelancaran Kas. 
Hasil output diinteprestasi menggunakan kriteria lebih kecil dari $\alpha$ yaitu 0,05 pada tingkat kepercayaan 95\% dengan kriteria sebagai berikut. $\mathrm{H}_{\mathrm{a}}$ diterima jika signifikansi $<0,05$, maka $\mathrm{H}_{0}$ ditolak yang artinya pada kondisi ini adalah ada perbedaan antara BPR Perseroan (PT) dengan BPR Perusahaan Daerah (PD) baik ditinjau dari Kredit Bermasalah maupun Kelancaran Kas.. Selanjutnya $\mathrm{H}_{\mathrm{a}}$ ditolak jika signifikansi $>0,05$, maka $\mathrm{HO}$ diterima, yaitu Tidak Ada perbedaan antara BPR Perseroan (PT) dengan BPR Perusahaan Daerah (PD) baik ditinjau dari Kredit Bermasalah maupun Kelancaran Kas.

Analisis Asumsi Dasar

\section{HASIL DAN PEMBAHASAN}

Salah satu asumsi dasar yang umumnya dipenuhi sebelum dilakukan analisis data dengan statistik induktif adalah terpenuhinya syarat data tersebut telah berdistribusi normal atau memenuhi normalitas data. Banyak cara melakukan uji normalitas data, misalkan saja dengan uji satu sampel kolmogorov-smirnov atau dengan metode yang biasanya menggunakan grafik normal probability plot dan kurva normal. Uji kolmogorov-smirnov menggunakan uji non-parametric dalam menghitung penyebaran data yang dianalisis. Pada metode grafik digunakan penilaian berdasarkan judgement atau penilaian gambar dari data yang dianalisis. Kedua metode sama-sama memiliki kelemahan dan kelebihan masingmasing, namun secara umum metode kolmogorov-smirnov lebih obyektif dalam menilai data tersebut, sedangkan metode grafik ternyata lebih mudah untuk dilakukan intepretasi tetapi terkesan ada unsur subyektif.

Hasil uji normalitas proxy-proxy yang dianalisis dalam rangka dilakukannya uji beda pada BPR berbentuk perseroan terbatas (PT) dan BPR berbentuk perusahaan daerah (PD) adalah:

Tabel 1, Hasil Uji Normalitas dengan Kolmogorov-Smirnov

\begin{tabular}{|c|c|c|c|}
\hline $\begin{array}{l}\text { The distribution of LANCAR is } \\
\text { normal with mean } 79.28 \text { and } \\
\text { standard deviation } 13.37 \text {. }\end{array}$ & $\begin{array}{l}\text { Qne-Sample } \\
\text { Kolmogorov- } \\
\text { Smirnov Test }\end{array}$ & .993 & $\begin{array}{l}\text { Retain the } \\
\text { null } \\
\text { hypothesis. }\end{array}$ \\
\hline $\begin{array}{l}\text { The distribution of } \\
\text { KREDITMASALAH is normal witl } \\
\text { mean } 9.90 \text { and standard deviati } \\
7.17 \text {. }\end{array}$ & $\begin{array}{l}\text { One-Sample } \\
\text { holmogorov- } \\
\text { OSmirnov Test }\end{array}$ & .281 & $\begin{array}{l}\text { Retain the } \\
\text { null } \\
\text { hypothesis. }\end{array}$ \\
\hline
\end{tabular}

Terlihat pada Tabel 1, tersebut bahwa sebagian besar data dari varibelproxy tersebut tidak berdistribusi normal. Hal ini tergambar dari nilai signifikansi yang lebih kecil (>) dari 0,05, yang berarti data berdistribusi normal. Hasil uji kolmogorov-smirnov keempat proxy tersebut menunjukkan Variabel Modal dan Likuiditas masing-masing menunjukkan signifikansi lebih besar yaitu 0,993 atau bermakna LDR telah berdistribusi normal. Selanjutnya variabel Kredit Bermasalah yang menggunakan proxy NPL. Nilainya menunjukan angka signifikansi 0,281 yang bermakna bahwa 
data NPL tersebut telah berdistribusi normal karena nilai signifikansi diatas 0,05 .

Analisis Beda (Perbandingan) dengan Uji t Independen

Analisis selanjutnya setelah didapatkannya asumsi dasar normalitas adalah melakukan uji Beda. Uji ini sering pula disebut dengan uji perbandingan yang dalam penelitian ini menggunakan analisis 2 sampel independent-sample t-test. Uji ini membandingkan rata-rata dari dua kelompok sampel data yang independen. Maksudnya diantara kedua hal yang diperbandingkan adalah masing-masing merupakan objek yang berbeda satu sama lainnya. Penggunaan independent t-test ini karena rata-rata yang dibandingkan hanya terdiri dua hal atau kategori saja, ketika lebih dari 2 maka dianjurkan menggunakan analisis of varians (anova).

Uji beda $t$ independen ini dilihat dari berbagai hal yaitu menggunakan proxy CAR yang mewakili variabel Modal dan variabel Likuiditas yang menggunakan proxy LDR. Hasil uji beda proxy-proxy tersebut tertuang selengkapnya pada Tabel 2. Pada tabel itu terdapat hasil pengujian levene's test yaitu pengujian untuk mengetahui apakah kedua data yang diperbandingkan memiliki tingkat homogenitas atau justru bersifat heterogen. Pengujian ini perlu dilakukan mengingat bahwa pada uji independent 2 sampel ini adalah membandingkan dua objek pengamatan atau dua proxy yang sama sekali tidak berhubungan atau tidak ada kaitannya sama sekali. Jadi ketika signifikansi levene's test tersebut lebih besar ( $>$ ) dari 0,05 maka data yang dianalisis memiliki varian yang sama atau data besifat homogen, sehingga uji beda sebaiknya menggunakan equal variances assumed. Sebaliknya jika ternyata signifikansi levene's test menghasilkan angka lebih kecil (<) dari 0,05 maka data memiliki ketidaksamaan varian atau data bersifat heterogen dan terkait dengan uji 2 sampel independent tersebut maka analisisnya disarankan menggunakan equal variances not assumed. Melalui uji levene's test ini diketahui data tersebut bersifat heterogen atau homogen sehingga dalam pengambilan keputusan dalam uji beda menjadi lebih akurat, karena jika mengetahui homogen berarti uji beda independentnya harus mengacu pada tingkat signifikansi pada equal variance assumed dan jika heterogen dilihat pada equal variance not assumed. 


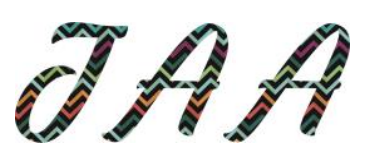

Vol. 5, No. 2, April 2021

Tabel 2, Hasil Independent t-test

Independent Samples Test

\begin{tabular}{|l|r|r|r|r|r|r|}
\hline \multirow{2}{*}{} & & $\begin{array}{c}\text { Levene's Test } \\
\text { for Equality of } \\
\text { Variances }\end{array}$ & \multicolumn{3}{|c|}{ t-test for Equality of Means } \\
\cline { 2 - 7 } & $\mathrm{F}$ & Sig. & $\mathrm{T}$ & Df & $\begin{array}{c}\text { Sig. } \\
(2- \\
\text { taile } \\
\text { d) }\end{array}$ & $\begin{array}{c}\text { Mean } \\
\text { Difference }\end{array}$ \\
\hline $\begin{array}{l}\text { Equal } \\
\text { variances } \\
\text { assumed } \\
\text { LANCAR }\end{array}$ & .328 & .572 & -3.934 & 27 & .001 & -17.74405 \\
$\begin{array}{l}\text { Equal } \\
\text { variances } \\
\text { not } \\
\text { assumed } \\
\text { Equal } \\
\text { variances } \\
\text { assumed } \\
\text { Equal } \\
\text { variances } \\
\text { not } \\
\text { assumed }\end{array}$ & 2.216 & .148 & .876 & 27 & .389 & 2.61905 \\
KREDIT \\
MASALA \\
H
\end{tabular}

Berdasarkan hasil pada Tabel 2, variabel KELANCARAN KAS dan KREDIT BERMASALAH menunjukkan tingkat signifikansi levene's test sebesar 0,572 dan 0,148 berdasarkan hasil levene test. Hal tersebut mengindikasikan bahwa semua data proxy tersebut memiliki tingkat homogenitas sehingga harus dianalisis berdasarkan equal variances assumed. Setelah mengetahui bahwa data yang diobservasi memiliki karakteristik yang sama (homogen), baru dilanjutkan dengan melakukan uji t-independen. Terkait hal tersebut maka Kelancaran Kas pada BPR Perseroan terbatas (PT) dan BPR Perusahaan Daerah (PD) tidak ada perbedaan karena tingkat signifikansinya sebesar 0,001 yang lebih kecil (<) dari 0,05 ditinjau dari hipotesis sebagai berikut.

HO : Tidak ada perbedaan antara KELANCARAN KAS BPR berbentuk perseroan terbatas (PT) dan BPR perusahaan daerah (PD).

$\mathrm{Ha}$ : Ada perbedaan antara KELANCARAN KAS BPR berbentuk perseroan terbatas (PT) dan BPR perusahaan daerah (PD).

Artinya dengan tingkat signifikansi yang lebih kecil dari 0,05 bahwa $\mathrm{Ha}$ diterima yaitu terdapat perbedaan antara KELANCARAN KAS pada BPR perseroan terbatas dengan BPR perusahaan daerah. 
Berikutnya KREDIT BERMASALAH dengan proxy NPL memiliki tingkat signifikansi sebesar 0,389 yang mengindikasikan tidak ada perbedaan antara likuiditas BPR Kecil dan BPR Menengah, dan berarti HO diterima. Hipotesis statistiknya adalah sebagai berikut.

HO : Tidak ada perbedaan antara KREDIT BERMASALAH BPR berbentuk perseroan terbatas (PT) dan BPR perusahaan daerah (PD).

$\mathrm{Ha}$ : Ada perbedaan antara KREDIT BERMASALAH BPR berbentuk perseroan terbatas (PT) dan BPR perusahaan daerah (PD).

Hasil tersebut memutuskan bahwa $\mathrm{HO}$ diterima atau berarti dari hipotesis statistik ini adalah bahwa tidak ada perbedaan kemampuan perusahaan dalam memantau pengembalian kredit yang diberikan antara BPR perseroan terbatas dan BPR perusahaan daerah.

\section{Pembahasan}

BPR konvensional yang saat ini aktif di Nusa Tenggara Barat (NTB) ada sebanyak 29 buah. Secara keseluruhan dari BPR-BPR tersebut mayoritas masuk kedalam kategori BPR yang berbentuk perseroan terbatas sebanyak 21 buah. Sisanya sebanyak 8 buah BPR tergolong dalam BPR yang dimiliki pemerintah daerah. Memang sesuai dengan tujuan pendiriannya, BPR ditujukan agar dapat membantu pihak Usaha Mikro, Kecil dan Menengah (UMKM) dan masyarakat yang tergolong dalam ekonomi lemah. Target pada UMKM ini menyebabkan pendapatan perusahaan relatif kecil. Selain pendapatan yang tidak besar, ketika BPR berhadapan dengan masyarakat ekonomi bawah maka risiko yang dihadapi akan semakin besar.Ada berbagai macam risiko yang dihadapi oleh pihak BPR misalnya risiko likuiditas, risiko permodalan, dan yang paling nyata adalah risiko kredit. Menurut Putra (2012) risiko kredit pada BPR relatif tinggi, sehingga menyebabkan kredit macet karena target pasarnya adalah kredit mikro.

Berikut gambaran perbedaan data yang diamati antara BPR Perseroan Terbatas dengan Perusahaan Daerah.

Tabel 3, Gambaran Data BPR Perseroan Terbatas dan Perusahaan Daerah

\begin{tabular}{|l|l|r|c|}
\hline & BADANUSAHA & $\mathrm{N}$ & Mean \\
\hline \multirow{2}{*}{ LANCAR } & PERSEROAN TERBATAS & 21 & 74.3810 \\
& PERUSAHAAN DAERAH & 8 & 92.1250 \\
KREDITMASALA & PERSEROAN TERBATAS & 21 & 10.6190 \\
H & PERUSAHAAN DAERAH & 8 & 8.0000 \\
\hline
\end{tabular}

Berdasarkan data pada Tabel 3 BPR berbentuk PT memiliki kelancaran kas yang diukur LDR dengan rata-rata 74,38\%. Artinya BPR Perseroan Terbatas memiliki kelancaran kas yang relatif rendah, karena standar kelancaran yang baik adalan diantara $89 \%$ sampai dengan $110 \%$. Berbeda 
dengan kondisi pada BPR Perseroan Terbatas, pada BPR Perusahaan Daerah

memiliki rata-rata 92,12. Hal tersebut menunjukan BPR kepemilikan daerah memiliki kelancaran kas yang baik yaitu diatas $89 \%$.

Selanjutnya ditinjau dari kredit bermasalah baik BPR dengan kepemilikan swasta maupun kepemilikan pemerintah daerah, sama-sama memiliki rata-rata kredit bermasalah yang tergolong tinggi. Keduanya memiliki rasio NPL diatas $5 \%$ yaitu masing-masing $10,6 \%$ untuk BPR Perseroan Terbatas dan $8 \%$ pada BPR Perusahaan Daerah. Hal tersebut menggambarkan pengawasan pemberian kredit BPR secara umum tergolong lemah.

\section{Pembahasan Perbedaan Dari KELANCARAN KAS}

Variabel likuiditas pada BPR salah satunya diukur dengan menggunakan proxy loan to deposit ratio (LDR) yang menggambarkan perbandingan atau rasio pemberian kredit terhadap jumlah simpanan pihak ketiga. Salah satu peranan bank dalam perekonomian sebagai lembaga yang memfasilitasi aliran dana yaitu seperti halnya bank konvensional maka BPR melakukan fungsi intermediasi. Fungsi tersebut memperjelas fungsi bank dalam menghimpun dana pihak ketiga berupa tabungan, deposito maupun giro yang kemudian disalurkan kembali dalam bentuk kredit kepada masyarakat. Pada Tabel 2, perbedaan rata-rata LDR BPR kepemilkan swasta (perseroan terbatas) dengan BPR kepemilikan pemerintah daerah adalah sebesar $17,74 \%$ yang berarti secara absolut berbeda jauh nilai likuiditas kedua BPR tersebut. Hal ini dipertegas kembali dengan hasil secara statistik induktif yang menjelaskan bahwa ada perbedaan antara BPR perseroan terbatas dan BPR perusahaan daerah ditinjau dari Likuiditas. Berdasarkan statistik deskriptif nilai LDR secara keseluruhan pada Tabel 3 adalah 79,27\% yang berarti kinerja likuiditas BPR di NTB tergolong tidak likuid karena berada dibawah angka yang ditetapkan Bank Indonesia sebesar 89\%. Artinya kemampuan menyalurkan kembali dana yang diperoleh dari masyarakat hanya $79 \%$.

Berdasarkan Tabel 3 menggambarkan nilai LDR untuk BPR berbentuk PT sebesar 74,38 \%, sedangkan BPR berbadan PD bernilai 92,12. Berarti BPR milik swasta memiliki kemampuan rendah dalam melakukan fungsi intermediasi atau dana yang dihimpun dari masyarakat hanya mampu disalurkan dalam bentuk kredit sebesar $74,38 \%$. Berbeda dengan hal tersebut BPR kepemilikan pemerintah daerah justru memiliki kinerja yang jauh lebih baik karena mampu menyalurkan kredit 92,12\% dari dana tabungan dan deposito. Hal tersebut mengindikasikan bahwa BPR kepemilikan pemerintah lebih dipilih oleh masyarakat untuk mendapatkan dana dalam bentuk kredit yang salah satu elemen utamanya adalah faktor bunga. Melalui tingkat bunga yang lebih rendah, maka masyarakat akan memilih mengambil keputusan dalam kredit. Kelancaran kas pada BPR 
Perusahaan Daerah yang lebih tinggi dan sehat tersebut disebabkan informasi dan jejaring pemerintah daerah kepada masyarakat ekonomi lemah yang memiliki potensi untuk diberi pembiayaan lebih tinggi dibandingkan BPR swasta. Pemerintah daerah tentu memiliki informasi menyeluruh terhadap karakteristik potensi masyarakat yang dapat diberikan pinjaman. Hal tersebut berdampak pada kemampuan intermediasi BPR berbentuk Perusahaan Daerah lebih mempunyai pelayanan berupa peminjaman kredit lebih tinggi dibanding perseroan terbatas. Cukup menerik memang Ketika ditelaah denga teori Agensi dari Jensen dan Meckling (1976) bahwa sepatutnya perusahaan memiliki kinerja lebih baik Ketika berbentuk kepemilikan manajerial, namun yang terjadi BPR milik perusahaan daerah memiliki likuiditas yang lebih baik jika dibandingkan dengan perseroan.

2. Pembahasan Perbedaan Dari Kredit Bermasalah

Kredit bermasalah merupakan hal lumrah terjadi pada lembaga keuangan dan perbankan. Terjadinya masalah tersebut ketika adanya debitur atau pelanggan yang mengambil kredit pada lembaga keuangan tertentu tidak dapat membayar angsuran pada tanggal yang telah ditentukan. Pengukuran atau proxy yang cukup populer yang digunakan dalam melihat kemampuan profitabilitas perusahaan adalah non performing loan (NPL) yang membandingkan junlah kredit yang tidak dapat ditagih dengan total kredit yang diberikan pada seluruh debitur. Artinya rasio ini memberi gambaran seberapa efektif pemantauan pemberian kredit kepada debitur. Tabel 3 menggambarkan bahwa BPR secara umum memiliki kredit bermasalah sebesar diatas 5\% yang berarti BPR konvensional di NTB telah memiliki kemampuan memntau kredit tergolong rendah, karena rata-rata NPL seluruh BPR yang ada di Provinsi NTB diatas standar ketentuan Bank Indonesia.

Hasil uji $t$ independen pada variabel kredit bermasalah menunjukkan bahwa ada perbedaan rata-rata proxy NPL antara BPR perseroan terbatas dengan BPR perusahaan daerah. Secara absolut hamper sama besarnya rata-rata kredit BPR berbentuk PT dengan BPR berbentuk PD pada Tabel 3 masing-masing 8\% dan 10,61\% dan hal tersebut memperkuat bukti setelah diuji beda tersebut bahwa tidak terdapat perbedaan kemampuan mengontrol kredit yang diberikan BPR kepada para nasabahnya. Banyak penyebab terjadinya kredit bermasalah baik secara intern dan ekstern (Sutojo, 2008). Hasil tersebut sama dengan Putra (2013) yang menunjukan tidak ada perbedaan ditinjau kredit bermasalah, bahkan setelah terjadinya merger pada BPR kondisi kredit bermasalah makin tinggi. Faktor intern penyebab kredit bermasalah antara lain rendahnya ketajaman analisis kredit, rendahnya system informasi kredit, campur tangan pemegang saham, dan pengikatan jaminan tidak sempurna. Faktor Ekstern penyebab kredit bermasalah adalah kegagalan usaha debitur, tingginya suku bunga, persaingan tidak sehat, dan musibah 
yang dialami perusahaan debitur. Melihat rendahnya kemampuan BPR di Nusa Tenggara Barat dalam mengawal pemberian kredit yang sehat pada nasabahnya, maka faktor internal bukanlah penyebab melainkan faktor eksternal sebagai penyebab utama. Rata-rata kredit bermasalah 9,8\% artinya hampir seluruh BPR di NTB mengalami pola penyebab kredit bermasalah dari luar perusahaan. Faktor eksternal yang paling sering sebagai penyebab adalah tingkat suku bunga pinjaman (kredit) yang relatif tinggi.

\section{KESIMPULAN}

Berdasarkan hasil analisis dan pembahasan pada bab sebelumnya, maka dapat disimpulkan bahwa:

Ada perbedaan antara BPR perseroan terbatas dan BPR perusahaan daerah ditinjau dari Likuiditas. Kemampuan menyalurkan kembali dana yang diperoleh dari masyarakat pada BPR berbentuk PT dibawah $89 \%$ sedangkan BPR berbadan PD diatas standar tersebut. Berarti BPR milik swasta memiliki kemampuan rendah dalam melakukan fungsi intermediasi. Berbeda dengan hal tersebut BPR kepemilikan pemerintah daerah justru memiliki kinerja yang jauh lebih baik. Hasil tersebut mengindikasikan bahwa BPR kepemilikan pemerintah memiliki informasi dan jejaring luas mengenai karakteristik masyarakat yang memiliki potensi untuk mendapat pembiayaan. Tidak Ada perbedaan rata-rata kemampuan mengontrol pemberian kredit antara BPR perseroan terbatas dengan BPR perusahaan daerah. Keduanya sama-sama memiliki tingkat kredit bermasalah yang tergolong tinggi, namun kemampuan mengontrol kredit pada BPR Kepemilikan Pemerintah Daerah lebih baik daripada BPR Perseroan Terbatas. Penyebab kredit bermasalah terindaksikan dari luar perusahaan karena BPR secara umum memiliki tingkat suku bunga pinjaman yang tinggi. Secara umum hasil ini menunjukan BPR perusahaan daerah memiliki kinerja lebih baik dari BPR perseroan terrbatas dan hasil tersebut merekomendasikan untuk saat ini dipertahankan apa yang telah ada dan dalam meningkatkan performa perlu memperkuat pengontrolan dan pengawasan pemberian kredit, melalui pemberian kredit 5 C (Chararcter, Colateral, Capital, Capacity dan Condition). 


\section{DAFTAR REFERENSI}

Anjani, D.P. dan Pakpahan R., 2020, Komparasi Kinerja Keuangan Bank Pemerintah dan Bank Swasta Nasional, Prosiding The 11th Industrial Research Workshop and National Seminar, pp.1048-1053

Dandapani, K., Lawrence, E.R., Patterson, F.M., 2017, The Effect of Holding Company Affiliation on Bank Risk and the 2008 Financial Crisis ", Studies in Economics and Finance, Vol. 34 Iss 1 pp. 1-33.

Chalermchavichien, Pichaphop, S. Jumreornvong, P. Jiraporn, dan M. Singh, 2011, The Effect of Bank Ownership on Capital Adequacy, Liquidity and Capital Stability (Basel II and Basel III), www.ssrn.com

Du, Xingqiang, 2013, Does Religion Matter to Owner-Manager Agency Costs? Evidence from China, Journal Business Ethic, 118, pp. 319-347.

Ghosh, A. 2017, "Impact of non-performing loans on US product and labor markets", Journal of Financial Economic Policy, Vol. 9 Issue: 3, pp.302-323.

Jensen, M.C. \& Meckling, W.H. 1976. Theory of The Firm: Managerial Behavior, Agency Cost and Capital Structure. Journal of Financial Economics, 3(4): 305- 360.

Putra, I.N.N.A., 2012, Kepemilikan Manajerial Dan Risiko Kredit Sebagai Pemicu Biaya Keagenan Pada Lembaga Keuangan Mikro, Jurnal Keuangan dan Perbankan, vol.16, no.3, pp. 437-444.

Putra, I.N.N.A., 2013, Perbedaan Profitabilitas dan Tingkat Pengawasan Sebelum dan Sesudah Merger Pada Bank Perkreditan Rakyat, Jurnal Keuangan dan Perbankan, vol.17, no.2, pp. 302-309.

Putri, I.D.A.D.E dan Damayanthi, I.G.A.E. 2013, Analisis Perbedaan Tingkat Kesehatan bank berdasarkan RGEC Pada perusahaan perbankan besar dan kecil, E-Jurnal Akuntansi Universitas Udayana, Vol.5, no.2, pp. 483-496.

Rashid, Afzalur, 2015, Revisiting Agency Theory: Evidence of Board Independence and Agency Cost from Bangladesh, Journal Business Ethic, 130, pp. 181-198.

Rubin, Amir, 2007, Ownership Level, Ownership Concentration, and Liquidity, Journal of Financial Markets, Vol. 10, Issue 3, August, pp. 219-248.

Sabrina, F.N., dan Muharam, H., 2015, Analisis Pengaruh Kepemilikan Pemerintah, Kepemilikan Asing, Risiko Likuiditas Dan Risiko Kredit 


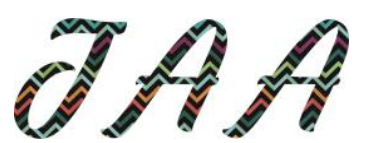

Vol. 5, No. 2, April 2021

Terhadap Kinerja Keuangan Bank, Diponegoro Journal Of Management, Vol.4, No.1, pp. 1-13.

Sarath, D., \& Pham D.V. 2015, The determinants of Vietnamese banks' lending behavior, Journal of Economic Studies, Vol. 42 Iss 5 pp. $861-877$.

Sukendri, N. 2021, Likuiditas Dan Permodalan Bank Milik Pemerintah Sebelum Dan Pada Masa Pandemi, Distribusi, vol. 9 No.1, pp. 109-119.

Tan, Y., dan Anchor J. 2017. Does competition only impact on insolvency risk? New evidence from the Chinese banking industry", International Journal of Managerial Finance, Vol. 13 Issue: 3, pp.1-35. 